\title{
Evaluation of adverse effects of chemotherapy regimens of 5- fluoropyrimidines derivatives and their association with DPYD polymorphisms in colorectal cancer patients
}

Reza Negarandeh ${ }^{1}$, Ebrahim Salehifar ${ }^{2^{*}}$, Fatemeh Saghafi ${ }^{3}$, Hossein Jalali $^{4}$, Ghasem Janbabaei ${ }^{5}$, Mohammad Javad Abdhaghighi ${ }^{6}$ and Anahita Nosrati ${ }^{7}$

\begin{abstract}
Background: 5-Fluorouracil (5-FU) and capecitabine are fluoropyrimidine derivatives that mainly metabolized with dihydropyrimidine dehydrogenase enzyme (DPD). The genetic polymorphism in the genes encoding this enzyme may result in a decrease or loss of enzyme activity which may lead to the accumulation of medicines, their metabolites and potential toxicity.

Method: This cross-sectional study was conducted on 88 participants with colorectal cancer (CRC). After DNA extraction, polymerase chain reaction-restriction fragment length polymorphism (PCR-RFLP) method was used to determine the DPD gene (DPYD) polymorphisms including IVS 14+1G>A, 2846 A > T and $2194 \mathrm{G}>\mathrm{A}$.

Chemotherapy-induced side effects were evaluated according to the Common Terminology Criteria for Adverse Events (CTCAE Version 5.0).

Result: Data were collected from 227 chemotherapy cycles of 88 patients with CRC. In a comparison of FOLFOX and FOLFIRI regimens, there was no significant difference in the occurrence of chemotherapy-induced diarrhea, nausea, vomiting and oral mucositis. However, the peripheral neuropathy was more frequent in patients who were treated with FOLFOX $(P<0.001)$ and hair loss was more common in patients who received FOLFIRI regimen $(P=0.048)$. Incidence of the DPD IVS14 + $1 \mathrm{G}>$ A polymorphism was observed in four patients (5.5\%). There was no association between IVS14 + $1 \mathrm{G}>$ A polymorphism and the occurrence of adverse reactions.
\end{abstract}

Conclusion: FOLFOX and FOLFIRI were the most common regimens in CRC patients and their toxicity profile was different in some adverse reactions. Prevalence of IVS14 + 1G > A variant was relatively higher than other similar studies. Trial registration: Approval code; IR.MAZUMS.REC.95.2480.

Keywords: Colorectal cancer, 5-fluorouracil, Polymorphism, Dihydropyrimidine dehydrogenase, Side effects

\footnotetext{
* Correspondence: Esalehifar@mazums.ac.ir; Salehifare@yahoo.com;

esalehifar52@gmail.com

${ }^{2}$ Pharmaceutical Research Center, Hemoglobinopathy institute, Department of Clinical Pharmacy, Mazandaran University of Medical Sciences, Sari, Iran Full list of author information is available at the end of the article
}

(c) The Author(s). 2020 Open Access This article is licensed under a Creative Commons Attribution 4.0 International License, which permits use, sharing, adaptation, distribution and reproduction in any medium or format, as long as you give appropriate credit to the original author(s) and the source, provide a link to the Creative Commons licence, and indicate if changes were made. The images or other third party material in this article are included in the article's Creative Commons licence, unless indicated otherwise in a credit line to the material. If material is not included in the article's Creative Commons licence and your intended use is not permitted by statutory regulation or exceeds the permitted use, you will need to obtain permission directly from the copyright holder. To view a copy of this licence, visit http://creativecommons.org/licenses/by/4.0/ The Creative Commons Public Domain Dedication waiver (http://creativecommons.org/publicdomain/zero/1.0/) applies to the data made available in this article, unless otherwise stated in a credit line to the data. 


\section{Background}

Nearly 50,000 incident cancer cases are reported in Iran annually. It has been reported that gastrointestinal (GI) cancers have the highest incidence rate in Iran [1]. CRC is the third most frequent cancer in the worldwide and is ranked third in terms of mortality [2]. There are different types of cancer treatments, including surgery, targeted therapies, and chemotherapy. The choice of therapy depends upon several factors such as tumor stage, molecular tumor indices, and functional status of the patient [3]. Fluoropyrimidine derivatives including 5FU and capecitabine (prodrug of 5-FU) inhibit the synthesis of thymidylate synthase (TS) leading to inhibition of synthesis of purine and pyrimidine bases [4-6]. 5-FU is a cytotoxic chemotherapy medicine that is widely used in the treatment of a variety of cancers, including colon, rectum, breast, stomach, and pancreas [7]. A substantial number of enzymes are involved in the metabolism of 5FU, First, thymidine phosphorylase (TP) catalyzes the conversion of 5 -FU to its active metabolite, 5-fluoro- $2^{\prime}$ deoxyuridine. Subsequently, 5'-fluoro-2-deoxyuridine converts to its active metabolite 5-fluoro- 2 '-deoxyuridine 5'-monophosphate (FdUMP) through phosphorylation by the thymidine kinase. FdUMP forms a ternary complex with methylene tetrahydrofolate and TS which finally lead to the inhibition of DNA synthesis. By inhibiting the participation of uracil in RNA, the complex will also inhibit RNA synthesis [5-8]. DPD is an enzyme present in the liver and accountable for about $80-85 \%$ of 5-FU catabolism. DPD catabolizes 5-FU to 5,6-dihydro-5-fluorouracil (DHFU) [5-9]. DPD deficiency can be associated with an exacerbation of diarrhea, nausea, vomiting, mucositis, and neurotoxicity of fluoropyrimidine derivatives [10]. The DPD enzyme is encoded by the DPYD and several single nucleotide polymorphisms (SNP) including IVS14 + 1G > A, 464 T > A, 2194 G > A, $496 \mathrm{~A}>\mathrm{G}$, and $1627 \mathrm{~A}>\mathrm{G}$ have been reported in the DPYD [11-13].

DPYD deficiency following absence or mutation of the allele reduces the 5-FU clearance and may increase the risk of developing severe toxicity. Mutation in some variants such as IVS14 + 1 G > A, $2846 \mathrm{~A}>\mathrm{T}$ and $2194 \mathrm{G}>\mathrm{A}$ may lead to reduced DPD enzyme levels [14].

The most common type of genetic polymorphism reported in patients with CRC that leads to a decrease or elimination of the activity of the DPD enzyme is mutation from guanine to adenine in DPYD of intron 14 called rs3918290 or IVS14 $+1 \mathrm{G}>\mathrm{A}$ or $* 2 \mathrm{~A}$ [15]. In addition to IVS14 +1G>A, other polymorphisms including 464 $\mathrm{T}>\mathrm{A}$ and $2194 \mathrm{G}>\mathrm{A}$ have also been associated with 5-FU side effects such as bone marrow depression and digestive tract complications [16]. Different chemotherapy regimens have been used in the treatment of CRC including FOLFOX (5-FU; $400 \mathrm{mg} / \mathrm{m}^{2} \mathrm{IV}$ bolus over $5 \mathrm{~min}$ and $2400 \mathrm{mg} / \mathrm{m}^{2}$ IV over $46 \mathrm{~h}$; leucovorin $400 \mathrm{mg} / \mathrm{m}^{2}$ IV day 1 and oxaliplatin $85 \mathrm{mg} / \mathrm{m}^{2} \mathrm{IV}$ day 1), FOLFIRI (5-FU $400 \mathrm{mg} / \mathrm{m} 2$ IV bolus over $5 \mathrm{~min}$ and $2400 \mathrm{mg} / \mathrm{m} 2 \mathrm{IV}$ over $46 \mathrm{~h}$; leucovorin $400 \mathrm{mg} / \mathrm{m}^{2} \mathrm{IV}$ and irinotecan $180 \mathrm{mg} / \mathrm{m}^{2} \mathrm{IV}$ ), and XELOX (capecitabine $1000 \mathrm{mg} / \mathrm{m} 2$ twice daily for 14 of every 21 days and oxaliplatin $130 \mathrm{mg} / \mathrm{m}^{2}$ on day 1$)[17,18]$.

The frequency of occurrence and severity of side effects of 5-FU and capecitabine may vary according to the type of chemotherapy regimen and interpersonal differences in the expression of genes encoding enzymes involved in the metabolism of drugs.

Further studies are required to have a better understanding of the association between DPYD polymorphism and the side effects of chemotherapy regimens of 5FU derivatives [19]. This study aimed to evaluate the adverse effects of different chemotherapy regimens used in CRC patients and the relationship between genetic polymorphism of DPYD and the adverse effects of chemotherapy regimens in a sample of CRC patients in the north of Iran.

\section{Methods}

From October of 2016 to June of 2017, this crosssectional study was carried out in outpatient oncology clinic of Imam Khomeini Hospital, Sari, Mazandaran. Eighty-eight patients with colon or rectal cancer were randomly assigned to receive either 5-FU or capecitabine in common chemotherapy regimens in use for CRC, including FOLFOX and FOLFIRI. Some of the patients were unable to continue the study due to different reasons including the changing of the medical center, discontinuing chemotherapy regimen, and death. Consequently, 73 patients were enrolled in this study. The study was approved by the Mazandaran University of Medical Sciences (MAZUMS) Review Board and all patients were given informed consent prior to participation in the study. The demographic and clinical data of patients including age, sex, tumor location, TNM stage (Tumor size, Lymph nodes involvement, Metastasis) and chemotherapy regimen were recorded.

Two milliliters of peripheral blood were collected from each participant and transferred to EDTA-containing tubes and then stored in a freezer at $-80^{\circ} \mathrm{C}$ until time of analysis.

Three SNP of DPYD gene including IVS14 + $1 \mathrm{G}>\mathrm{A}$, $2194 \mathrm{~A}>\mathrm{G}$ and $2846 \mathrm{~A}>\mathrm{T}$ were studied based on PCRRFLP method.

Genomic DNA was extracted from peripheral blood using the QIA Amp DNA Mini kit (Qiagen, Germany). PCR-RFLP method was used to determine the IVS14 + 1 $\mathrm{G}>\mathrm{A}$ and $2846 \mathrm{~A}>\mathrm{T}$ variants applying Mae II and Bse8I restriction enzymes, respectively. Tetra-primer ARMSPCR was optimized to detect the $2194 \mathrm{G}>\mathrm{A}$ variant. 
Amplification performed with an initial denaturation step $\left(5 \mathrm{~min}\right.$ at $95^{\circ} \mathrm{C}$ ) followed by 35 cycles of $95^{\circ} \mathrm{C}$ for $1 \mathrm{~min}$, $60{ }^{\circ} \mathrm{C}$ for $1 \mathrm{~min}$ for IVS14 $+1 \mathrm{G}>\mathrm{A}$ variant, $62^{\circ} \mathrm{C}$ for 2846 $\mathrm{A}>\mathrm{T}, 58^{\circ} \mathrm{C}$ for $2846 \mathrm{~A}>\mathrm{T}$ variants, and then $72{ }^{\circ} \mathrm{C}$ for 1 min followed by an extension step of $72^{\circ} \mathrm{C}$ for $5 \mathrm{~min}$ [20].

Side effects experienced by patients including diarrhea, nausea, vomiting, mucositis, peripheral neuropathy, and hair loss were recorded and graded according to CTCAE Version 5.0 [21].

Data analysis was performed using SPSS 24 software. Mean and standard deviation was reported for quantitative data and qualitative dichotomous data were presented as frequency and percent. Comparison of qualitative data was done using Chi-square test. In all cases, $P<0.05$ was considered a statistically significant difference.

\section{Results}

The demographic and clinical characteristics of patients are presented in Table 1. The colon cancer incidence was more frequent compared to rectal cancer incidence. Most patients had a disease with a TNM stage of 3 or 4 (71\%). FOLFOX (72.7\%) and FOLFIRI (20.8\%) were the most used regimens compared to other chemotherapy regimens (93.5\% versus $6.5 \%$ ).

Additionally, the prevalence of $D P Y D$ polymorphisms, including IVS $14+1 \mathrm{G}>\mathrm{A}, 2846 \mathrm{~A}>\mathrm{T}$, and $2194 \mathrm{G}>\mathrm{A}$, was determined in 73 patients (Table 2).

IVS14 + 1G > A polymorphism was found in 4 of 73 patients $(5.5 \%)$, all of which were heterozygous. There were no cases of two other polymorphisms (2846 A > T and $2194 \mathrm{G}>\mathrm{A}$ ).

The frequencies of chemotherapy-related side effects were summarized in Table 3.

Patients treated with FOLFOX showed higher rate of peripheral neuropathy $(96 \%$ versus $76.6 \%, P<0.001)$, whereas FOLFIRI regimen was associated with a higher occurrence of hair loss $(58.5 \%$ vs. $40 \%, P=0.04)$. The rate of other adverse effects including diarrhea, nausea, vomiting and oral mucositis were not different. The severity of the side effects experienced with each of the chemotherapy cycles was presented in the Table 4.

The grading of most of the adverse reactions was not statistically different for FOLFOX and FOLFIRI regimens, except hair loss. A higher grade toxicity (grade 2) was more common with FOLFIRI compared to FOLFOX (20.8\% versus $5.4 \%, P=0.034)$. In the case of diarrhea, 5 out of 41 patients who received FOLFIRI (12\%) and 13 out of 140 patients who received FOLFOX (9.2\%) experienced grade 3/ 4 diarrhea $(P=0.95)$. Grade 3 nausea was observed only in one case of FOLFOX regimen and there was not any Grade 3 or 4 nausea with FOLFIRI regimen $(P=0.32)$. Vomiting Grade $3 / 4$ was observed in 14.3 and $11.1 \%$ of patients received FOLFOX and FOLFIRI, respectively $(\mathrm{P}=0.9)$.
Table 1 Demographic and clinical data of patients $(n=88)$

\begin{tabular}{|c|c|}
\hline \multicolumn{2}{|l|}{ Age; year } \\
\hline Mean & 58.7 \\
\hline SD & 12.9 \\
\hline \multicolumn{2}{|l|}{ Sex; number (\%) } \\
\hline Male & $48(54.5)$ \\
\hline Female & $40(45.5)$ \\
\hline \multicolumn{2}{|l|}{ Site of Cancer; number(\%) } \\
\hline Colon & $64(72.7)$ \\
\hline Rectum & $24(27.3)$ \\
\hline \multicolumn{2}{|l|}{ Tumor stage; number(\%) } \\
\hline Stage $2 a$ & $9(12.3)$ \\
\hline Stage $2 b$ & $8(11)$ \\
\hline Stage $2 \mathrm{c}$ & $3(4.1)$ \\
\hline Stage $3 a$ & $3(4.1)$ \\
\hline Stage $3 b$ & $14(19.2)$ \\
\hline Stage $3 c$ & $6(8.2)$ \\
\hline Stage $4 a$ & $25(34.2)$ \\
\hline Stage $4 b$ & $5(6.9)$ \\
\hline \multicolumn{2}{|c|}{ Chemotherapy; number of cycles(\%) } \\
\hline FOLFOX & $165(72.7)$ \\
\hline FOLFIRI & $47(20.7 \%)$ \\
\hline Capecitabine + Cetuximab & $3(1.3)$ \\
\hline Capecitabine & $6(2.7)$ \\
\hline FOLOFOX-IRI & $5(2.2)$ \\
\hline $5-\mathrm{FU}$ & $1(0.4)$ \\
\hline
\end{tabular}

5-FU 5-Fluorouracil, FOLFOX: 5-FU leucovorin and oxaliplatin, FOLFIRI: 5-FU leucovorin and irinotecan; colorectal cancer TNM staging was accordant to the American Joint Committee on Cancer staging manual (8th edition)

Grade 3/4 oral mucositis occurred in 11.4 and $16.7 \%$ of patients treated with FOLFOX and FOLFIRI, respectively $(P=0.59)$. Peripheral neuropathy was a common adverse effect with both FOLFOX and FOLFIRI regimens, but almost all patients experienced Grade 1 or 2 toxicity. Grade 3 toxicity of peripheral neuropathic symptom occurred only in one patient with a FOLFOX regimen $(P=0.39)$.

The incidence of adverse drug reactions considering IVS14 + 1G > A polymorphism was presented in Table 5 . Diarrhea, vomiting, oral mucositis, peripheral neuropathy, and hair loss were not different between patients with and without IVS14 $+1 \mathrm{G}>\mathrm{A}$ polymorphism.

All of the patients with IVS14 + 1G > A polymorphism showed hair loss, whereas $50.7 \%$ of patients who did not have this polymorphism experienced this side effect $(P=0.093)$.

There was no significant difference between the presence or absence of IVS14 + 1G > A polymorphism with incidence of diarrhea ( $25 \%$ vs. $23.2 \% ; P=0.663$ ), nausea 
Table 2 The prevalence of DPYD gene polymorphisms ( $n=73$ )

\begin{tabular}{lllll}
\hline Polymorphism & Heterozygous & Homozygote & Absence of polymorphism & Total \\
\hline IVS 14+1 G > A & $4(5.5 \%)$ & 0 & $69(94.5 \%)$ & $73(100 \%)$ \\
2846 A > T & 0 & 0 & $73(100 \%)$ & $73(100 \%)$ \\
2194 G $>$ A & 0 & 0 & $73(100 \%)$ & $73(100 \%)$ \\
\hline
\end{tabular}

(zero vs. $43.5 \% ; P=0.113$ ), vomiting ( $25 \%$ vs. $23.2 \%$; $\mathrm{P}=$ $0.663)$, oral mucositis (50\% vs. $39.1 \% ; P=0.522)$, and peripheral neuropathy (100\% vs. $92.8 \%, P=0.748)$.

\section{Discussion}

The aim of the current study was to investigate the prevalence of adverse drug reactions of 5-FU based chemotherapy regimens used in the treatment of CRC and the relationship between three polymorphisms of $D P Y D$ including IVS $14+1 \mathrm{G}>\mathrm{A}, 2846 \mathrm{~A}>\mathrm{T}$, and 2194 $\mathrm{G}>\mathrm{A}$ with the occurrence of adverse drug reactions. Various mutations of the DPYD have been reported [22, 23]. In an Italian survey, Mazzuca et al. reported that the prevalence of IVS14 + 1G > A polymorphism in CRC patients was $1.38 \%$, all of which were heterozygous. In comparison with our study, a few percentages of patients had $D P Y D$ IVS14 + 1G > A polymorphism as compared to the rate of $5.5 \%$ in our patients. Similar to our study, all of these polymorphisms were heterozygous. The incidence of severe side effects (Grade 3/4) was similar between the two studies ( $21.2 \%$ versus $18.2 \%$ in our study) [24].

Lee et al., Reported an incidence of IVS14 + 1G > A in 2886 Caucasian patients treated with 5-FU containing regimens including FOLFOX and FOLFIRI. Among all patients, $0.94 \%$ was heterozygous. Compared to the present study population, a few percent of patients had $D P Y D$ IVS $14+1 G>A$ polymorphism and all of these polymorphisms were heterozygous. In $33.1 \%$ of patients (859 cases), severe side effects (Grade 3 and above) were due to 5 -FU and $88 \%$ of patients with the IVS $14+1 \mathrm{G}>\mathrm{A}$ polymorphism experienced severe side effects compared to patients without this polymorphism (57.1\% vs. $18.1 \%)$. Common symptoms reported were diarrhea (12\%), neutropenia (11.7\%), nausea and vomiting (5\%), fatigue (4.9\%), and mucositis (4.2\%) [25]. In this study, the prevalence of diarrhea, nausea, vomiting, oral mucositis, peripheral neuropathy, and hair loss was 24.7, 30.8, 19.4, 34.4, 92.1 and 46.7\%, respectively. We did not find any

Table 3 Adverse drug reactions of chemotherapy regimens

\begin{tabular}{|c|c|c|c|c|c|c|c|c|c|}
\hline \multirow[t]{2}{*}{$\overline{A D R}$} & \multicolumn{8}{|c|}{ Chemotherapy regimens } & \multirow[t]{2}{*}{$\boldsymbol{P}$-Value* } \\
\hline & & FOLOFOX & FOLFIRI & $\begin{array}{l}\text { Capecitabine + } \\
\text { Cetuximab }\end{array}$ & Capecitabine & $\begin{array}{l}\text { FOLOFOX + } \\
\text { Irinotecan }\end{array}$ & $5-\mathrm{FU}$ & Total & \\
\hline \multirow[t]{3}{*}{ Diarrhea } & Exist & $39(23.6 \%)$ & $14(29.8 \%)$ & 0 & $1(16.7 \%)$ & $2(40 \%)$ & $0(0 \%)$ & $56(24.7 \%)$ & \multirow[t]{3}{*}{0.39} \\
\hline & Absent & $126(76.4 \%)$ & $33(70.2 \%)$ & $3(100 \%)$ & $5(83.3 \%)$ & $3(60 \%)$ & $1(100 \%)$ & $171(75.3 \%)$ & \\
\hline & Total & 165 & 47 & 3 & 6 & 5 & 1 & 227 & \\
\hline \multirow[t]{3}{*}{ Nausea } & Exist & $48(29.1 \%)$ & $14(29.8 \%)$ & $2(66.7 \%)$ & $2(33.3 \%)$ & $3(60 \%)$ & $1(100 \%)$ & 70 (30.8\%) & \multirow[t]{3}{*}{0.93} \\
\hline & Absent & $117(70.95 \%)$ & $33(70.25 \%)$ & $1(33.3 \%)$ & $4(66.7 \%)$ & $2(40 \%)$ & $0(0 \%)$ & $157(69.2 \%)$ & \\
\hline & Total & 165 & 47 & 3 & 6 & 5 & 1 & 227 & \\
\hline \multirow[t]{3}{*}{ Vomiting } & Exist & $28(17 \%)$ & $9(19.1 \%)$ & 1 (33.3\%) & $2(33.3 \%)$ & $3(60 \%)$ & $1(100 \%)$ & 44 (19.4\%) & \multirow[t]{3}{*}{0.73} \\
\hline & Absent & $137(83 \%)$ & $38(80.9 \%)$ & $2(66.7 \%)$ & $4(66.7 \%)$ & $2(40 \%)$ & $0(0 \%)$ & 183 (80.6\%) & \\
\hline & Total & 165 & 47 & 3 & 6 & 5 & 1 & 227 & \\
\hline \multirow[t]{3}{*}{ Oral mucositis } & Exist & $55(33.3 \%)$ & 18 (38.3\%) & $0(0 \%)$ & $2(33.3 \%)$ & $2(60 \%)$ & $1(100 \%)$ & 78 (34.4\%) & \multirow[t]{3}{*}{0.53} \\
\hline & Absent & $110(66.7 \%)$ & $29(61.7 \%)$ & $3(100 \%)$ & $4(66.7 \%)$ & $3(40 \%)$ & $0(0 \%)$ & 149 (65.6\%) & \\
\hline & Total & 165 & 47 & 3 & 6 & 5 & 1 & 227 & \\
\hline \multirow{3}{*}{$\begin{array}{l}\text { Peripheral } \\
\text { neuropathy }\end{array}$} & Exist & 159 (96.4\%) & $36(76.6 \%)$ & $3(100 \%)$ & $5(83.3 \%)$ & $5(100 \%)$ & $1(100 \%)$ & 209 (92.1\%) & \multirow[t]{3}{*}{$<0.001$} \\
\hline & Absent & $6(3.6 \%)$ & $11(23.4 \%)$ & $0(0 \%)$ & $1(16.7 \%)$ & $0(0 \%)$ & $0(0 \%)$ & 18 (7.9\%) & \\
\hline & Total & 165 & 47 & 3 & 6 & 5 & 1 & 227 & \\
\hline \multirow[t]{3}{*}{ Hair loss } & Exist & $56(40 \%)$ & $24(58.5 \%)$ & $2(66.7 \%)$ & $5(83.3 \%)$ & $3(75 \%)$ & $1(100 \%)$ & 91 (46.7\%) & \multirow[t]{3}{*}{0.04} \\
\hline & Absent & $84(60 \%)$ & 17 (41.2\%) & $1(33.3 \%)$ & $1(16.7 \%)$ & $1(25 \%)$ & $0(0 \%)$ & 104 (53.3\%) & \\
\hline & Total & 140 & 41 & 3 & 6 & 4 & 1 & 195 & \\
\hline
\end{tabular}


Table 4 Severity of adverse effects of chemotherapy regimens

\begin{tabular}{|c|c|c|c|c|c|c|c|c|c|}
\hline \multirow[t]{2}{*}{$\overline{A D R}$} & \multicolumn{8}{|c|}{ Chemotherapy regimens } & \multirow[t]{2}{*}{$\boldsymbol{P}$-value } \\
\hline & & FOLOFOX & FOLFIRI & $\begin{array}{l}\text { Capecitabine + } \\
\text { Cetuximab }\end{array}$ & Capecitabine & $\begin{array}{l}\text { FOLOFOX + } \\
\text { Irinotecan }\end{array}$ & $5-\mathrm{FU}$ & Total & \\
\hline \multirow[t]{4}{*}{ Diarrhea } & Grade 1 & $14(35.9 \%)$ & $4(28.6 \%)$ & $0(0 \%)$ & $1(100 \%)$ & $2(100 \%)$ & $0(0 \%)$ & $21(37.5 \%)$ & \multirow[t]{4}{*}{0.96} \\
\hline & Grade 2 & $12(30.8 \%)$ & $5(35.7 \%)$ & $0(0 \%)$ & $0(0 \%)$ & $0(0 \%)$ & $0(0 \%)$ & 17 (30.4\%) & \\
\hline & Grade 3 & $7(17.9 \%)$ & $3(21.4 \%)$ & $0(0 \%)$ & $0(0 \%)$ & $0(0 \%)$ & $0(0 \%)$ & $10(17.9 \%)$ & \\
\hline & Grade 4 & $6(15.4 \%)$ & $2(14.3 \%)$ & $0(0 \%)$ & $0(0 \%)$ & $0(0 \%)$ & $0(0 \%)$ & $8(14.3 \%)$ & \\
\hline \multirow[t]{3}{*}{ Nausea } & Grade 1 & $33(68.8 \%)$ & $7(50 \%)$ & $1(50 \%)$ & $2(100 \%)$ & $2(66.7 \%)$ & $0(0 \%)$ & $45(64.3 \%)$ & \multirow[t]{3}{*}{0.32} \\
\hline & Grade 2 & $14(29.2 \%)$ & $7(50 \%)$ & $1(50 \%)$ & $0(0 \%)$ & $1(33.3 \%)$ & $1(100 \%)$ & $24(34.3 \%)$ & \\
\hline & Grade 3 & $1(2.1 \%)$ & $0(0 \%)$ & $0(0 \%)$ & $0(0 \%)$ & $0(0 \%)$ & $0(0 \%)$ & $1(1.4 \%)$ & \\
\hline \multirow[t]{4}{*}{ Vomiting } & Grade 1 & $17(6.7 \%)$ & $5(55.6 \%)$ & $1(100 \%)$ & $2(100 \%)$ & $1(33.3 \%)$ & $1(100 \%)$ & $27(61.4 \%)$ & \multirow[t]{4}{*}{0.91} \\
\hline & Grade 2 & $7(25 \%)$ & $3(33.3 \%)$ & $0(0 \%)$ & $0(0 \%)$ & $2(66.7 \%)$ & $0(0 \%)$ & $12(27.3 \%)$ & \\
\hline & Grade 3 & $3(10.7 \%)$ & $1(11.1 \%)$ & $0(0 \%)$ & $0(0 \%)$ & $0(0 \%)$ & $0(0 \%)$ & $4(9.1 \%)$ & \\
\hline & Grade 4 & $1(3.6 \%)$ & $0(0 \%)$ & $0(0 \%)$ & $0(0 \%)$ & $0(0 \%)$ & $0(0 \%)$ & $1(2.3 \%)$ & \\
\hline \multirow[t]{4}{*}{ Oral mucositis } & Grade 1 & $24(61.4 \%)$ & $11(61.1 \%)$ & $0(0 \%)$ & $0(0 \%)$ & $1(50 \%)$ & $0(0 \%)$ & $36(46.2 \%)$ & \\
\hline & Grade 2 & $19(27.3 \%)$ & $4(22.2 \%)$ & $0(0 \%)$ & $2(100 \%)$ & $1(50 \%)$ & $1(100 \%)$ & $27(34.6 \%)$ & \multirow[t]{3}{*}{0.59} \\
\hline & Grade 3 & $11(9.1 \%)$ & $3(16.7 \%)$ & $0(0 \%)$ & $0(0 \%)$ & $0(0 \%)$ & $0(0 \%)$ & $14(17.9 \%)$ & \\
\hline & Grade 4 & $1(2.3 \%)$ & $0(0 \%)$ & $0(0 \%)$ & $0(0 \%)$ & $0(0 \%)$ & $0(0 \%)$ & $1(1.3 \%)$ & \\
\hline \multirow[t]{3}{*}{ Peripheral neuropathy } & Grade 1 & $89(56 \%)$ & $16(44.4 \%)$ & $0(0 \%)$ & $2(40 \%)$ & $4(80 \%)$ & $0(0 \%)$ & $111(53.1 \%)$ & \multirow[t]{3}{*}{0.39} \\
\hline & Grade 2 & $69(43.4 \%)$ & $20(55.6 \%)$ & $3(100 \%)$ & $2(40 \%)$ & $1(20 \%)$ & $1(100 \%)$ & $96(45.9 \%)$ & \\
\hline & Grade 3 & $1(0.6 \%)$ & $0(0 \%)$ & $0(0 \%)$ & $1(20 \%)$ & $0(0 \%)$ & $0(0 \%)$ & $2(1 \%)$ & \\
\hline \multirow[t]{2}{*}{ Hair loss } & Grade 1 & $53(94.6 \%)$ & 19 (79.2\%) & $2(100 \%)$ & $5(100 \%)$ & $1(33.3 \%)$ & $0(0 \%)$ & 80 (87.9\%) & \multirow[t]{2}{*}{0.03} \\
\hline & Grade 2 & $3(5.4 \%)$ & $5(20.8 \%)$ & $0(0 \%)$ & $0(0 \%)$ & $2(66.7 \%)$ & $1(100 \%)$ & 11 (12.1\%) & \\
\hline
\end{tabular}

$A D R$ adverse drug reaction, 5-FU 5-Fluorouracil, FOLFOX 5-FU / leucovorin and oxaliplatin, FOLFIRI 5-FU / leucovorin and irinotecan; *: P-value represents the difference between FOLFOX and FOLFIRI regimens

association between the IVS $14+1 \mathrm{G}>\mathrm{A}$ polymorphism and the occurrence of side effects.

Deenen et al. studied the effect of DPYD polymorphisms on the toxicity and effect of Capecitabine on disease progression of 568 Dutch patients with CRC.
Patients were received regimes containing Oxaliplatin and Capecitabine and the prevalence of IVS14 + 1G > A polymorphism was $1 \%$, that was less than the amount detected in our study. The results showed a significant correlation between polymorphisms and side effects of

Table 5 Frequency of adverse drug reactions in different variants of IVS14 + 1G > A

\begin{tabular}{|c|c|c|c|c|c|}
\hline \multirow[b]{2}{*}{ ADR } & \multicolumn{5}{|c|}{ Polymorphism IVS14 + 1G > A } \\
\hline & & Heterozygous & Normal & Total & $P$-value \\
\hline \multirow[t]{2}{*}{ Diarrhea } & Exist & $1(1.4 \%)$ & $16(21.9 \%)$ & $17(23.3 \%)$ & 0.663 \\
\hline & Absent & $3(4.1 \%)$ & $53(72.6 \%)$ & $56(76.7 \%)$ & \\
\hline \multirow[t]{2}{*}{ Nausea } & Exist & 0 & $30(41.1 \%)$ & $30(41.1 \%)$ & 0.113 \\
\hline & Absent & $4(5.5 \%)$ & $39(53.4 \%)$ & $43(58.9 \%)$ & \\
\hline \multirow[t]{2}{*}{ Vomiting } & Exist & $1(1.4 \%)$ & $16(21.9 \%)$ & $17(23.3 \%)$ & 0.663 \\
\hline & Absent & $3(4.1 \%)$ & $53(72.6 \%)$ & $56(76.7 \%)$ & \\
\hline \multirow[t]{2}{*}{ Oral mucositis } & Exist & $2(2.7 \%)$ & $27(37 \%)$ & $29(39.7 \%)$ & 0.522 \\
\hline & Absent & $2(2.7 \%)$ & $42(57.6 \%)$ & $44(60.3 \%)$ & \\
\hline \multirow[t]{2}{*}{ Peripheral neuropathy } & Exist & $4(5.5 \%)$ & $64(87.7 \%)$ & 68 (93.2\%) & 0.748 \\
\hline & Absent & 0 & $5(6.8 \%)$ & $5(6.8 \%)$ & \\
\hline \multirow[t]{2}{*}{ Hair loss } & Exist & $4(5.5 \%)$ & $37(50.7 \%)$ & $41(56.2 \%)$ & 0.093 \\
\hline & Absent & 0 & 32 (43.8\%) & 32 (43.8\%) & \\
\hline
\end{tabular}


Capecitabine. Five out of seven of the patients with IVS141G > A polymorphism experienced diarrhea (71\%). All patients with IVS141G $>$ A polymorphism showed Grade 3 or 4 diarrhea symptoms [13].

Unlike our study, He et al. did not see the IVS14+ $1 \mathrm{G}>$ A polymorphism in 142 Chinese patients with colorectal and nasopharyngeal cancers [26].

In a study conducted by Uzunkoy et al. in 2007 on 56 patients with CRC cancer in Turkey, they found two cases of IVS14 $+1 \mathrm{G}>$ A polymorphism $(0.6 \%)$, both of which were heterozygous [27]. The rate of IVS14 +1G > A heterozygous polymorphism was less in their study compared to our population studied.

In a study conducted by Raida et al. in Germany, of 851 Caucasian patients with CRC treated with 5-FU, the prevalence of IVS14+1G > A was $0.94 \%$, all of which were heterozygous, and approximately $25 \%$ of those who experienced Grade 3 and 4 had this polymorphism [28]. The prevalence of IVS14 +1G $>$ A polymorphism was higher in our population.

Different populations and races show different prevalence of IVS14 + 1G > A polymorphism in the DPYD [29]. In a study on 72 patients in Taiwan, $2.7 \%$ of patients had IVS14 + 1G > A polymorphism in the DPYD [30]. However, in another study on 262 patients in Taiwan, this polymorphism was not observed [31]. DPD enzyme activity was reported to be higher than normal in North Korea [8] that may influence the efficacy and toxicity of fluoropyrimidine-based adjuvant chemotherapy.

In addition to IVS14 $+1 \mathrm{G}>\mathrm{A}$ polymorphism, in this study we also examined the presence of other DPYD polymorphism including A > T 2846 and $2194 \mathrm{G}>\mathrm{A}$, but these polymorphisms were not observed in our patients. Lee et al. reported that the prevalence of $\mathrm{A}>\mathrm{T} 2846$ polymorphism in 2886 Caucasian patients with Grade 3 colon cancer who received FOLFOX and FOLFIRI regimens was about $1.1 \%$ [25]. In a study by Terrazzino et al. on 2308 patients, the prevalence of $2846 \mathrm{~A}>\mathrm{T}$ polymorphisms was $0.2 \%$ [32].

Deenen et al. reported that $2194 \mathrm{G}>\mathrm{A}$ polymorphism in 568 Dutch patients with CRC receiving the XELOX regimen was about $7 \%$, and they observed the relationship between severity of diarrhea (Grade 3/4) and 2194G > A polymorphism [13]. But in another study conducted on 142 Chinese patients with colorectal and nasopharyngeal cancers receiving 5 -FU-treated regimens, the prevalence of the $2194 \mathrm{G}>\mathrm{A}$ polymorphism was reported $1.4 \%$ and there was not any relationship with the DPD enzyme activity [26]. Although efforts have been made to determine the association between the DPYD and the 5-FU toxicities, it seems that DPYD alone can detect approximately $20 \%$ of the early side effects of 5FU [15]. Present study shows that there was no significant correlation between IVS14 + $1 \mathrm{G}>\mathrm{A}$ polymorphism and the profile of side effects of 5-
FU in CRC patients. It other words, a major part of the symptoms experienced by patients is independent of $D P Y D$ polymorphism. But the results of our study should be interpreted cautiously as the sample size of our study was small and the relevant SNPs was only observed in four cases.

\section{Conclusion}

Among the studied polymorphisms, only the IVS14+ $1 \mathrm{G}>\mathrm{A}$ polymorphism was found in our patients and its prevalence was somewhat higher than the similar studies. Two other polymorphisms including $2194 \mathrm{G}>\mathrm{A}$ and 2846 $\mathrm{A}>\mathrm{T}$ were not found. FOLFOX and FOLFIRI regimens were used more than other regimens. The profile of toxicities of FOLFOX and FOLFIRI regimens was different in some adverse reactions such as peripheral neuropathy and alopecia and we did not observe any relationship between adverse reactions and DPYD polymorphism.

\section{Abbreviations}

5-FU: 5-Fluorouracil; ADR: Adverse drug reaction; CRC: Colorectal cancer; CTCAE: Common terminology criteria for adverse events;

DHFU: Dihydrofluorouracil; DPD: Dihydropyrimidine dehydrogenase enzyme; DPYD: DPD gene; FdUMP: 5-fluoro-2'-deoxyuridine 5'-monophosphate; FOLFIRI: 5-FU, leucovorin, and irinotecan; OLFOX: 5-FU, leucovorin and oxaliplatin; PCR-RFLP: Polymerase chain reaction-restriction fragment length polymorphism; SNP: Single nucleotide polymorphisms; TNM disease stage: Tumor size, lymph nodes involvement, metastasis; TS: Thymidylate synthase; XELOX: Capecitabine and oxaliplatin

\section{Acknowledgements}

The authors would like to thank Faculty of Pharmacy of Mazandaran University of Medical Science (MAZUMS), Sari, Iran for financially supported and staff of outpatient oncology clinic of Imam Khomeini Hospital, Sari, Mazandaran for their protection and cooperation. Also, we would like to thank reviewers for providing comment and suggestion that helped us improve quality and clarity of manuscript.

\section{Authors' contributions}

ES conceived and designed the project, analyzed the data, interpretation of the results of analysis and edited manuscript. RN contributed to the sample collections, followed-up the patients, collected data, analyzed the data, interpretation of the results of analysis and wrote the manuscript. FS edited manuscript. GJ and AN were project consultant. $\mathrm{HJ}$ and $\mathrm{MHAH}$ were responsible for PCR test. All authors read and approved the final version of the manuscript.

\section{Funding}

This study was financially supported by a grant (grant no. 95.2480) from the Research and Technology Department of Mazandaran University of Medical Sciences, Sari, Iran, which contributed to sequencing and analysis support. The funding bodies had no role in the decision to publish and or writing of the manuscript. This manuscript is in partial fulfillment of the Requirements for the Degree of Pharm-D of Reza Negarandeh.

Availability of data and materials

The datasets used and/or analyzed during the current study are available from the corresponding author on reasonable request.

Ethics approval and consent to participate

All patients signed an informed consent to participation in the study. The study on human specimens was approved by the Ethics Committee of Mazandaran University of Medical Sciences, Sari, Iran (approval no. IR.MAZUMS.REC.95.2480). 


\section{Consent for publication}

Not applicable.

\section{Competing interests}

The authors declare that they have no competing interests.

\section{Author details}

'Department of Pharmaceutics, Facuity of Pharmacy, Mazandaran University of Medical Sciences, Sari, Iran. ${ }^{2}$ Pharmaceutical Research Center, Hemoglobinopathy institute, Department of Clinical Pharmacy, Mazandaran University of Medical Sciences, Sari, Iran. ${ }^{3}$ Department of Clinical Pharmacy, Faculty of Pharmacy and Pharmaceutical Sciences Research Center, Shahid Sadoughi University of Medical Sciences, Yazd, Iran. ${ }^{4}$ Thalassemia Research Center, Mazandaran University of Medical Sciences, Sari, Iran. ${ }^{5}$ Gastrointestinal Cancer Research Center, Faculty of Medicine, Mazandaran University of Medical Sciences, Sari, Iran. ${ }^{6}$ Department of Pharmacognosy, Facuity of Pharmacy, Mazandaran University of Medical Sciences, Sari, Iran. ${ }^{7}$ Department of Pathology, Imam Khomeini Hospital, Mazandaran University of Medical Sciences, Sari, Iran

\section{Received: 6 September 2019 Accepted: 26 April 2020}

\section{Published online: 16 June 2020}

\section{References}

1. Alireza S, Mehdi N, Ali M, Alireza M, Reza M, Parkin D. Cancer occurrence in Iran in 2002, an international perspective. Asian Pac J Cancer Prev. 2005;6(3): 359

2. Jemal A, Simard EP, Dorell C, Noone A-M, Markowitz LE, Kohler B, et al. Annual report to the nation on the status of cancer, 1975-2009, featuring the burden and trends in human papillomavirus (HPV)-associated cancers and HPV vaccination coverage levels. JNCl. 2013;105(3):175-201.

3. Marley AR, Nan H. Epidemiology of colorectal cancer. Int J Mol Epidemiol Genet. 2016;7(3):105

4. Chu E, DeVita Jr VT. Physicians' Cancer Chemotherapy Drug Manual 2018: Jones \& Bartlett Learning; 2017

5. Li X, Kong X, Kong X, Wang Y, Yan S, Yang Q. 53BP1 sensitizes breast cancer cells to 5-fluorouracil. PLoS One. 2013:8(9):e74928.

6. Bai W, Wu Y, Zhang P, Xi Y. Correlations between expression levels of thymidylate synthase, thymidine phosphorylase and dihydropyrimidine dehydrogenase, and efficacy of 5-fluorouracil-based chemotherapy for advanced colorectal cancer. Int J Clin Exp Pathol. 2015;8(10):12333-45.

7. Chai J, Dong W, Xie C, Wang L, Han DL, Wang S, et al. MicroRNA-494 sensitizes colon cancer cells to fluorouracil through regulation of DPYD. IUBMB Life. 2015:67(3):191-201.

8. Liu XQ, Zhuang M, Wang Z, Huber RM. Correlation between dihydropyrimidine dehydrogenase and efficacy and toxicity of fluoropyrimidine drugs. Eur Rev Med Pharmacol Sci. 2014;18(18): 2772-6.

9. Cai X, Fang JM, Xue P, Song WF, Hu J, Gu HL, et al. The role of IVS14+1 G > a genotype detection in the dihydropyrimidine dehydrogenase gene and pharmacokinetic monitoring of 5-fluorouracil in the individualized adjustment of 5-fluorouracil for patients with local advanced and metastatic colorectal cancer: a preliminary report. Eur Rev Med Pharmacol Sci. 2014; 18(8):1247-58.

10. Teh LK, Hamzah S, Hashim H, Bannur Z, Zakaria ZA, Hasbullani Z, et al. Potential of dihydropyrimidine dehydrogenase genotypes in personalizing 5-fluorouracil therapy among colorectal cancer patients. Ther Drug Monit. 2013;35(5):624-30.

11. Gross E, Busse B, Riemenschneider M, Neubauer S, Seck K, Klein H-G, et al. Strong association of a common dihydropyrimidine dehydrogenase gene polymorphism with fluoropyrimidine-related toxicity in cancer patients. PLoS One. 2008;3(12):e4003.

12. Amstutz $U$, Froehlich TK, Largiadèr CR. Dihydropyrimidine dehydrogenase gene as a major predictor of severe 5 -fluorouracil toxicity. Pharmacogenomics. 2011;12(9):1321-36.

13. Deenen MJ, Tol J, Burylo AM, Doodeman VD, de Boer A, Vincent A, et al, Relationship between single nucleotide polymorphisms and haplotypes in DPYD and toxicity and efficacy of capecitabine in advanced colorectal cancer. Clin Cancer Res. 2011;17(10):3455-68.

14. Offer SM, Fossum CC, Wegner NJ, Stuflesser AJ, Butterfield GL, Diasio RB. Comparative functional analysis of DPYD variants of potential clinical relevance to dihydropyrimidine dehydrogenase activity. Cancer Res. 2014; 74(9):2545-54.

15. Kristensen M, Pedersen P, Melsen G, Ellehauge J, Mejer J. Variants in the dihydropyrimidine dehydrogenase, methylenetetrahydrofolate reductase and thymidylate synthase genes predict early toxicity of 5fluorouracil in colorectal cancer patients. J Int Med Res. 2010;38(3): 870-83.

16. Li Q, Liu Y, Zhang HM, Huang YP, Wang TY, Li DS, et al. Influence of DPYD genetic polymorphisms on 5 -fluorouracil toxicities in patients with colorectal Cancer: a meta-analysis. Gastroenterol Res Pract. 2014;2014: 827989.

17. Gustavsson B, Carlsson G, Machover D, Petrelli N, Roth A, Schmoll H-J, et al. A review of the evolution of systemic chemotherapy in the management of colorectal cancer. Clin Colorectal Cancer. 2015;14(1):1-10.

18. Guo $Y$, Xiong B-H, Zhang T, Cheng Y, Ma L. XELOX vs. FOLFOX in metastatic colorectal cancer: an updated meta-analysis. Cancer Investig. 2016;34(2):94-104

19. Mohelnikova-Duchonova B, Melichar B, Soucek P. FOLFOX/FOLFIRI pharmacogenetics: the call for a personalized approach in colorectal cancer therapy. World J Gastroenterol: WJG. 2014;20(30):10316.

20. Hoseini SM, Montazeri F, Froughmand AM, Dehghani M, Ghadimi HR. Introduction to genetic testing-applications, advantages and disadvantages. Genet 3rd millennium. 2014;12:3544-63.

21. Savarese DM. Common terminology criteria for adverse events. UpToDate Waltham, MA: UpToDate. 2013

22. van KUILENBURG AB, Dobritzsch $D$, Meinsma $R$, Haasjes J, Waterham HR, Nowaczyk MJ, et al. Novel disease-causing mutations in the dihydropyrimidine dehydrogenase gene interpreted by analysis of the three-dimensional protein structure. Biochem J. 2002;364(1):157-63.

23. van Kuilenburg AB, Haasjes J, Richel DJ, Zoetekouw L, Van Lenthe H, De Abreu RA, et al. Clinical implications of dihydropyrimidine dehydrogenase (DPD) deficiency in patients with severe 5-fluorouracil-associated toxicity: identification of new mutations in the DPD gene. Clin Cancer Res. 2000; 6(12):4705-12

24. Mazzuca F, Borro M, Botticelli A, Mazzotti E, Marchetti L, Gentile G, et al. Pretreatment evaluation of 5 -fluorouracil degradation rate: association of poor and ultra-rapid metabolism with severe toxicity in a colorectal cancer patients cohort. Oncotarget. 2016;7(15):20612-20.

25. Lee AM, Shi Q, Pavey E, Alberts SR, Sargent DJ, Sinicrope FA, et al. DPYD variants as predictors of 5 -fluorouracil toxicity in adjuvant colon cancer treatment (NCCTG N0147). J Natl Cancer Inst. 2014;106(12):dju298.

26. He YF, Wei W, Zhang X, Li YH, Li S, Wang FH, et al. Analysis of the DPYD gene implicated in 5-fluorouracil catabolism in Chinese cancer patients. J Clin Pharm Ther. 2008:33(3):307-14.

27. Uzunkoy A, Dilmec F, Ozgonul A, van KUILENBURG AB, Akkafa F. Investigation of IVS14+ 1G> a polymorphism of DPYD gene in a group of Turkish patients with colorectal cancer. Anticancer Res. 2007;27(6B):3899-902.

28. Raida M, Schwabe W, Häusler P, Van Kuilenburg AB, Van Gennip AH, Behnke $D$, et al. Prevalence of a common point mutation in the dihydropyrimidine dehydrogenase (DPD) gene within the 5'-splice donor site of intron 14 in patients with severe 5 -fluorouracil (5-FU)-related toxicity compared with controls. Clin Cancer Res. 2001;7(9):2832-9.

29. Shin JG, Cheong HS, Kim JY, Kim LH, Han CS, Kim JO, et al. Screening of dihydropyrimidine dehydrogenase genetic variants by direct sequencing in different ethnic groups. J Korean Med Sci. 2013;28(8):1129-33.

30. Wei X, McLeod HL, McMurrough J, Gonzalez FJ, Fernandez-Salguero P. Molecular basis of the human dihydropyrimidine dehydrogenase deficiency and 5-fluorouracil toxicity. J Clin Invest. 1996;98(3):610-5.

31. van Kuilenburg AB. Dihydropyrimidine dehydrogenase and the efficacy and toxicity of 5-fluorouracil. Eur J Cancer. 2004;40(7):939-50.

32. Terrazzino S, Cargnin S, Del Re M, Danesi R, Canonico PL, Genazzani AA. DPYD IVS14+ 1G> a and 2846A> T genotyping for the prediction of severe fluoropyrimidine-related toxicity: a meta-analysis. Pharmacogenomics. 2013; 14(11):1255-72.

\section{Publisher's Note}

Springer Nature remains neutral with regard to jurisdictional claims in published maps and institutional affiliations. 